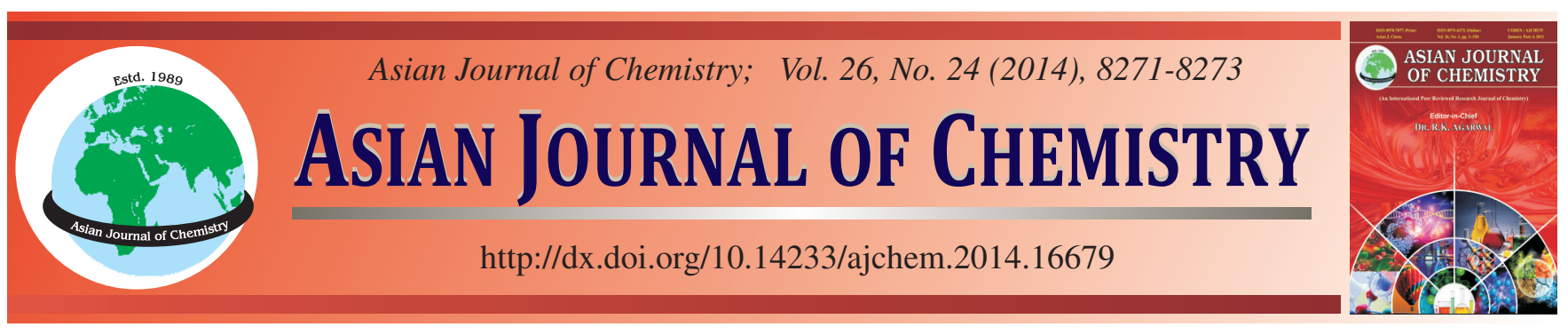

\title{
A New Dihydroxanthenone from the Fermentation Products of Endophytic Fungus of Phomopsis amygdali
}

Limei Li, Huan Wang, JuanXia Yang, Jie Lou, Guiyou Liu, Xuemei Gao, Qiufen Hu and Yanqing Ye*

Key Laboratory of Chemistry in Ethnic Medicinal Resources, State Ethnic Affairs Commission \& Ministry of Education, Yunnan University of Nationalities, Kunming 650031, P.R. China

*Corresponding author: E-mail: yey-qing@163.com

Keywords: Dihydroxanthone, Phomopsis fungus, Fermentation products, Cytotoxicity.

\section{INTRODUCTION}

The Phomopsis species known as an important phytopathogenic genus contains more than 900 species named from a wide range of hosts ${ }^{1}$. These microorganisms produce a number of secondary metabolites with various biological activities, including antimicrobial ${ }^{2,3}$, antifungal ${ }^{4,5}$, antimalarial ${ }^{6,7}$, antitumor ${ }^{7,8}$, etc. The xanthone derivatives are impor-tant metabolites isolated from the Phomopsis genus and they appeals to medicinal chemists because of their pronounced pharmacological effects ${ }^{9,10}$.

With the aim of multipurpose utilization endophytic fungus of isolated from the rhizome of Paris polyphylla var. yunnanensis and identify bioactive natural products, the phytochemical investigation on fermentation products of the endophytic fungus Phomopsis amygdali. was carried out. As a result, a new dihydroxanthone (1) (Fig. 1) was isolated. In addition, the cytotoxicity of compound $\mathbf{1}$ was evaluated. This article reported the isolation, structure elucidation and cytotoxicity of the new compound.<smiles>COc1cc(CO)cc2oc3c(c(=O)c12)C(C(=O)O)[C@H](O)C=C3</smiles>

Fig. 1. Structure of $\mathbf{1}$

\section{EXPERIMENTAL}

Optical rotations were measured with a Horiba SEPA300 polarimeter. UV spectra were obtained using a Shimadzu UV-2401A spectrophotometer. IR spectra were obtained in $\mathrm{KBr}$ disc on a Bio-Rad Wininfmred spectrophotometer. ESIMS were measured on a VG Auto Spec-3000 MS spectrometer. ${ }^{1} \mathrm{H},{ }^{13} \mathrm{C}$ and 2D NMR spectra were recorded on Bruker DRX500 instrument with TMS as internal standard. Column chromatography was performed on silica gel (200-300 mesh), or on silica gel H (10-40 mm, Qingdao Marine Chemical Inc., China). Second separate was used an Agilent 1100 HPLC equipped with ZORBAX-C18 (21.2 $\mathrm{mm} \times 250 \mathrm{~mm}, 7 \mathrm{~mm})$ column and DAD detector.

The culture of Phomopsis sp. was isolated from the rhizome of Paris polyphylla var. yunnanensis collected from Shizhong, Yunnan, People's Republic of China, in 2011. The strain was identified by Gang Du based on the analysis of the ITS sequence. It was cultivated at room temperature for 7 days on potato dextrose agar at $28{ }^{\circ} \mathrm{C}$. Agar plugs were inoculated into 250 $\mathrm{mL}$ Erlenmeyer flasks each containing $100 \mathrm{~mL}$ potato dextrose broth and cultured at $28^{\circ} \mathrm{C}$ on a rotary shaker at $180 \mathrm{rpm}$ for 5 days. Large scale fermentation was carried out in 50 Fernbach flasks $(500 \mathrm{~mL})$ each containing $100 \mathrm{~g}$ of rice and $120 \mathrm{~mL}$ of distilled $\mathrm{H}_{2} \mathrm{O}$. Each flask was inoculated with $5 \mathrm{~mL}$ of cultured broth and incubated at $25^{\circ} \mathrm{C}$ for 45 days.

Extraction and isolation: The fermentation products were extracted four times with $70 \%$ acetone $(4 \times 5 \mathrm{~L})$ at room temperature and filtered. The crude extract $(42.5 \mathrm{~g})$ was applied 
TABLE-1

${ }^{1} \mathrm{H}-\mathrm{AND}{ }^{13} \mathrm{C}-\mathrm{NMR}$ DATA OF COMPOUND 1 (500 AND $125 \mathrm{MHz}, \mathrm{IN} \mathrm{CD}_{3} \mathrm{OD}$ )

\begin{tabular}{ccccc}
\hline No. & $\delta_{\mathrm{C}}(\mathrm{m})$ & $\delta_{\mathrm{H}}(\mathrm{m}, J, \mathrm{~Hz})$ & No. & $\delta_{\mathrm{C}}(\mathrm{m})$ \\
\hline 1 & $47.5 \mathrm{~d}$ & $4.22 \mathrm{~d}(3.8)$ & 9 & $183.2 \mathrm{~s}$ \\
2 & $65.2 \mathrm{~d}$ & $4.68 \mathrm{dd}(3.8,4.8)$ & $4 \mathrm{a}$ & $158.4 \mathrm{~s}$ \\
3 & $137.6 \mathrm{~d}$ & $6.45 \mathrm{~d}(4.8,9.9)$ & $8 \mathrm{a}$ & $110.9 \mathrm{~s}$ \\
4 & $123.8 \mathrm{~d}$ & $6.68 \mathrm{dd}(9.9)$ & $9 \mathrm{a}$ & $112.2 \mathrm{~s}$ \\
5 & $106.2 \mathrm{~d}$ & $6.95 \mathrm{~s}$ & $10 \mathrm{a}$ & $156.4 \mathrm{~s}$ \\
6 & $149.5 \mathrm{~s}$ & & $1^{\prime}$ & $176.4 \mathrm{~s}$ \\
7 & $108.5 \mathrm{~d}$ & $6.74 \mathrm{~s}$ & $2^{\prime}$ & $65.1 \mathrm{t}$ \\
8 & $162.8 \mathrm{~s}$ & & $8-\mathrm{OMe}$ & $55.9 \mathrm{q}$ \\
\hline
\end{tabular}

to silica gel (200-300 mesh) column chromatography, eluting with a $\mathrm{CHCl}_{3}$-acetone gradient system $(20: 1,9: 1,8: 2,7: 3,6: 4$, 5:5), to give six fractions A-F. The further separation of fraction $\mathrm{D}(7: 3,6.53 \mathrm{~g})$ by silica gel column chromatography and preparative HPLC ( $32 \% \mathrm{MeOH}$, flow rate $12 \mathrm{~mL} / \mathrm{min}$ ) to give $1(5.4 \mathrm{mg})$.

(1R,2R)-2-hydroxy-6-(hydroxymethyl)-8-methoxy-9oxo-2,9-dihydro- $\mathbf{H}$-xanthene-1-carboxylic acid (1): yellow gum; $[\alpha]_{\mathrm{D}}^{24.5}-8.21$ (c 0.20, MeOH); UV $\left(\mathrm{CH}_{3} \mathrm{OH}\right), \lambda_{\max }(\log$ ع) 340 (3.82), 272 (4.14), $210(4.38) \mathrm{nm}$; IR (KBr, $\left.v_{\max }, \mathrm{cm}^{-1}\right)$ : 3420, 2945, 2850, 1752, 1654, 1602, 1538, 1455, 1416, 1274, $1158,1072,966,857 ;{ }^{13} \mathrm{C}$ NMR and ${ }^{1} \mathrm{H}$ NMR data (500 and $125 \mathrm{MHz}$, in $\mathrm{CD}_{3} \mathrm{OD}$ ) see Table-1; positive ESIMS $\mathrm{m} / z, 341$ $[\mathrm{M}+\mathrm{Na}]^{+}$; positive HRESIMS $m / z 341.0632[\mathrm{M}+\mathrm{Na}]^{+}(\mathrm{calcd}$ for $\mathrm{C}_{16} \mathrm{H}_{14} \mathrm{NaO}_{7}, 341.0637$ ).

\section{RESULTS AND DISCUSSION}

A $70 \%$ aq. acetone extract prepared from fermentation products of the endophytic fungus Phomopsis amygdali was subjected repeatedly to column chromatography on Silica gel, Sephadex LH-20, RP-18 and Preparative HPLC to afford compound 1. The structure of $\mathbf{1}$ was shown in Fig. 1 and its ${ }^{1} \mathrm{H}$ and ${ }^{13} \mathrm{C}$ NMR data were listed in Table-1.

Compound 1 was obtained as a yellow powder: The molecular formula was established as $\mathrm{C}_{16} \mathrm{H}_{14} \mathrm{NaO}_{7} \mathrm{~m} / z, 341.0632$ $[\mathrm{M}+\mathrm{Na}]^{+}$(calcd. for 341.0637), which indicated 10 degrees of unsaturation. Its UV spectrum showed the maximum absorption at 340, 272 and $210 \mathrm{~nm}$. Strong absorption bands accounting for hydroxy $\left(3420 \mathrm{~cm}^{-1}\right)$, carbonyl $\left(1752,1654 \mathrm{~cm}^{-1}\right)$ and aromatic groups $\left(1602,1538,1455 \mathrm{~cm}^{-1}\right)$ could also be observed in its IR spectrum. The ${ }^{13} \mathrm{C}$ and DEPT spectra of $\mathbf{1}$ revealed 16 carbon, composed of one methoxy group $\left(\delta_{\mathrm{C}} 55.9\right)$, one methine group $\left(\delta_{\mathrm{C}} 47.5\right)$, one oxidized methine group $\left(\delta_{\mathrm{C}} 65.2\right)$, one oxidized methylene group $\left(\delta_{\mathrm{C}} 65.1\right)$, four aromatic methines $\left(\delta_{\mathrm{C}} 137.6,123.8,106.2\right.$ and 108.5$)$, six aromatic quatern $\left(\delta_{\mathrm{C}}\right.$ $149.5,162.8,158.4,110.9,112.2$ and 156.4) and two carbonyl carbons $\left(\delta_{\mathrm{C}} 183.2\right.$ and 176.4$)$. The ${ }^{13} \mathrm{C}$ NMR signal 176.4 was assigned to a carbonyl group. The ${ }^{1} \mathrm{H}$ NMR spectrum revealed four aromatic protons $\left[\delta_{\mathrm{H}}(6.74 \mathrm{~s}),(6.95 \mathrm{~s}),(6.45 \mathrm{~d}, J=9.9\right.$, $4.8 \mathrm{~Hz})$ and $(6.68 \mathrm{dd}, J=9.9 \mathrm{~Hz})$. Two aromatic protons at $\delta_{\mathrm{H}}$ $6.45(\mathrm{~d}, J=9.9,4.8 \mathrm{~Hz})$ and $6.68(\mathrm{dd}, J=9.9 \mathrm{~Hz})$ were connected to those at $\delta_{\mathrm{H}} 4.68(\mathrm{dd} J=3.8,4,8 \mathrm{~Hz})$ and $4.22(\mathrm{~d}$, $J=3.8 \mathrm{~Hz}$ ).

This connectivity was confirmed by correlation of these four protons ${ }^{1} \mathrm{H}-{ }^{1} \mathrm{H}$ COSY spectrum (Fig. 2). In addition, one methoxy and one hydroxymethyl protons appeared at $\delta_{\mathrm{H}} 3.81$ (s) and 4.65 (s), respectively. The precise connectivities between proton and carbon signals were established by interpretation of HMBC data. In HMBC spectrum of 1 , the proton at $\delta_{\mathrm{H}} 4.22$ $(\mathrm{H}-1)$ was correlated with C-2 $\left(\delta_{\mathrm{C}} 65.2\right), \mathrm{C}-3\left(\delta_{\mathrm{C}} 137.6\right), \mathrm{C}-4 \mathrm{a}$ $\left(\delta_{\mathrm{C}} 158.4\right), \mathrm{C}-9\left(\delta_{\mathrm{C}} 183.2\right), \mathrm{C}-9 \mathrm{a}\left(\delta_{\mathrm{C}} 112.2\right)$. These correlations indicated the existence of dihydroxanthenone skeleton ${ }^{11}$. The HMBC correlations (Fig. 2) of the methoxy proton signal $\left(\delta_{\mathrm{H}}\right.$ $3.81)$ with $C-8\left(\delta_{\mathrm{C}} 162.8\right)$ suggested the methoxy group should be located at C-8. The hydroxymethyl group located at C-6 was supported by the HMBC correlations of $\mathrm{H}-2^{\prime}\left(\delta_{\mathrm{H}} 4.65\right)$ with C-5 $\left(\delta_{\mathrm{C}} 106.2\right), \mathrm{C}-6\left(\delta_{\mathrm{C}} 149.5\right)$ and C-7 $\left(\delta_{\mathrm{C}} 108.5\right)$. Furthermore, a hydroxy group should be located at C-2 to support the existence of an oxidized methylene. The configurations of $1 \mathrm{R}$, $2 \mathrm{R}$ in 1 were deduced from the comparison of ${ }^{1} \mathrm{H}$ and ${ }^{13} \mathrm{C} \mathrm{NMR}$ data, coupling constants and ROESY correlations with these of AGI-B4, ${ }^{11}$ of which configuration was unambiguously established by an X-ray structure analysis. According to above informations, compound 1 was assigned as (1R, 2R)-2-hydroxy-6(hydroxymethyl)-8-methoxy-9-oxo-2,9-dihydro-1H-xanthene1 -carboxylic acid.

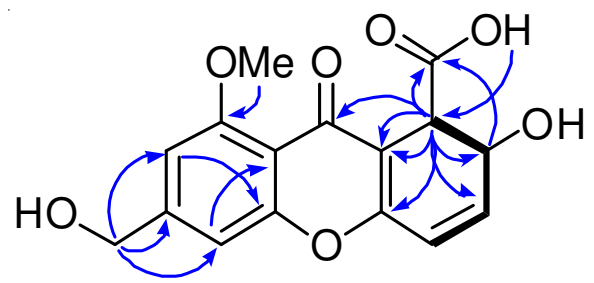

Fig. 2. Key $\mathrm{HMBC}(\frown)$ and ${ }^{1} \mathrm{H}-{ }^{1} \mathrm{H}$ COSY $(\square)$ correlations of $\mathbf{1}$

Xanthones are known to exhibit cytotoxic effects ${ }^{6,9,12}$. Compound $\mathbf{1}$ were tested for its cytotoxicity against five tumor cells line (NB4, A549, SHSY5Y, PC3 and MCF7) using a previously reported procedure ${ }^{13}$. The results showed that $\mathbf{1}$ exhibited high cytotoxicity against NB4 and PC3 cell with $\mathrm{IC}_{50}$ values of 4.5 and $3.8 \mu \mathrm{M}$.

\section{ACKNOWLEDGEMENTS}

This research was supported by the National Natural Science Foundation of China (No. 21302164), the Excellent Scientific and Technological Team of Yunnan High School (2010CI08), the Yunnan University of Nationalities Green Chemistry and Functional Materials Research for Provincial Innovation Team (2011HC008), the National Undergraduates Innovating Experimentation Project (2011HX18) and startup funds of Yunnan University of Nationalities. 


\section{REFERENCES}

1. D. Udayanga, X. Liu, E.H.C. McKenzie, E. Chukeatirote, A.H.A Bahkali and K.D. Hyde, Fungal Divers., 50, 189 (2011).

2. J.N. Choi, J. Kim, K. Ponnusamy, C. Lim, J.G. Kim, M.J. Muthaiya and C.H. Lee, J. Antibiot, 66, 231 (2013).

3. H. Hussain, M.K. Tchimene, I.K. Ahmed, M. Steinert, S. Draeger, B. Schulz and K. Krohn, Nat. Prod. Commun, 6, 1905 (2011).

4. H. Hussain, I. Ahmed, B. Schulz, S. Draeger and K. Krohn, Fitoterapia, 83, 523 (2012)

5. H. Hussain, K. Krohn, I. Ahmed, S. Draeger, B. Schulz, S. Di Pietro and G. Pescitelli, Eur. J. Org. Chem., 1783 (2012).

6. M. Isaka, A. Jaturapat, K. Rukseree, K. Danwisetkanjana, M. Tanticharoen and Y. Thebtaranonth, J. Nat. Prod., 64, 1015 (2001).
7. C. Hemtasin, S. Kanokmedhakul, K. Kanokmedhakul, C. Hahnvajanawong, K. Soytong, S. Prabpai and P. Kongsaeree, J. Nat. Prod., 74, 609 (2011).

8. E. Adelin, C. Servy, S. Cortial, H. Lévaique, M.-T. Martin, P. Retailleau, G. Le Goff, B. Bussaban, S. Lumyong and J. Ouazzani, Phytochemistry, 72, 2406 (2011).

9. K.S. Masters and S. Brase, Chem. Rev., 112, 3717 (2012).

10. S. Kaul, S. Gupta, M. Ahmed and M.K. Dhar, Phytochem. Rev., 11, 487 (2012).

11. H.S. Kim, I.Y. Park, Y.J. Park, J.H. Lee, Y.S. Hong and J.J. Lee, J. Antibiot, 55, 669 (2002).

12. Q. Hu, X. Gao, D. Niu, X. Li, Y. Qin, Z. Yang, G. Zhao, Z. Yang and Z. Chen, Heterocycles, 87, 1127 (2013).

13. X.M. Gao, R.R. Wang, D.Y. Niu, C.Y. Meng, L.M. Yang, Y.T. Zheng, G.Y. Yang, Q.F. Hu, H.D. Sun and W.L. Xiao, J. Nat. Prod., 76, 1052 (2013). 